\title{
Pengembangan obyek wisata di Kawasan Danau Buatan PLTA Koto Panjang Kabupaten Kampar Oleh:
}

\author{
${ }^{1}$ Eka, ${ }^{2}$ Trio Saputra, ${ }^{3}$ Aguswan
}

Program Studi Administrasi Publik, Universitas Lancang Kuning

Email.1eka@gmail.com,

\begin{abstract}
Abstrak
Pengembangan obyek wisata di kawasan danau buatan PLTA koto Panjang Kabupaten Kampar. Penelitian di laksanakan di kawasan Danau Buatan PLTA koto panjang Kabupaten Kampar merupakan area Pembangkit Listrik Tenaga Air (PLTA) yang dapat menyuplay kebutuhan listrik di tiga provinsi yaitu (Riau, Jambi dan Sumbar). pada kawasan tersebut juga dimamfaatkan masyarakat sebagai tempattempat wisata, sehingga dapat di kunjungan oleh masyarakat umum dan menjadi potensi wisata kabupaten Kampar yang dapat dikembangkan. Pendekatan action resech digunakan untuk menelusuri obyek wisata alam yang berada dilingkungan PLTA Koto panjang Kampar. Obyek wisata tersebut belum tertata dan terkelola dengan baik,.namun antusias dan kemauan msyarakat desa untuk mengembangkan dan memamfaatkan sumber daya alam di kawasan PLTA koto panjang sangat tinggi. Hal ini dibuktikan dengan terbentuknya beberapa kelompok sadar wisata (POKDARWIS) yaitu sebagai usaha kelompok yang peduli dengan keindahan lingkungan alam wisata di desa tersebut. Hasil penelitian menggambarkan bahwa kondisi pengembangan obyek wisata danau buatan hanya pada fase eksplorasi (penemuan) dan fase keterlibatan (involment) artinya bahwa kegiatan pengembangan wisata di danau PLTA kito panjang sebatas penemuan obyek wisata baru yang digali atau dikembangkan oleh sebagian kecil kelompok masyarakat atau dengan melibatkan sebagian orang atau kelompok yang berkeinginan mengembangkan obyek-obyek wisata di Danau Buatan PLTA Koto panjang seperti kehadiran kelompok sadarwisata yang berkeinginan mengembangkan obyek wisata dengan swadaya seadanya.
\end{abstract}

Kata Kunci: Pengembangan, obyek wisata, PLTA, Koto Panjang

\begin{abstract}
Development of tourism objects in the lake area made by PLTA Koto Panjang Kampar District. Research conducted in the area of Lake artificial PLTA koto Panjang Kampar District is an area of hydroelectric power (PLTA) that can supply electricity needs in three provinces (Riau, Jambi and West Sumatra). In the area is also made public as a place to visit, so it can be visited by the general public and become tourism potentials of Kampar district that can be developed. The approach of action Resech is used to trace natural attractions located in the PLTA Koto long Kampar. The tourism object is not yet organized and managed properly,. But enthusiastic and willingness to village to develop and cultivate natural resources in the area of Koto PLTA very high length. This is evidenced by the formation of several tourism conscious groups (POKDARWIS) as a group business that cares about the beauty of the natural environment of the village. The results illustrate that the condition of development of artificial lake tourism objects only in the exploration phase (discovery) and the involment phase, means that tourism development activities in the lake of PLTA Kito long as the invention of new tourism object excavated or developed by a small part of the community or by involving some people or groups who wish to develop tourism objects at the PLTA Koto artificial lake as long as the presence of a sadarwisata group that wishes to develop tourism objects with a lack of self-reliance.
\end{abstract}

Keywords: Development, tourism objects, PLTA, Koto panjang 
Japs: Jurnal Administrasi Politik dan Sosial, Vol. 1 No 1, April 2020

https://japs.ejournal.unri.ac.id/

\section{PENGEMBANGAN OBYEK WISATA DI KAWASAN DANAU BUATAN PLTA KOTO PANJANG KABUPATEN KAMPAR}

\section{PENDAHULUAN}

Danau buatan PLTA koto Panjang merupakan suatu kawasan pusat pembangkit listrik Tenaga Air (PLTA) terletak di jalan Raya Provinsi Riau - Sumatera barat, bertempat di Desa Koto Mesjid Kecamatan XIII Koto Kampar Kabupaten Kampar Provinsi Riau. PLTA Koto Panjang mampu mensuplay kebutuhan energi listrik untuk 3( tiga) Provinsi di Indonesia yaitu Provinsi Riau, Provinsi Sumatera barat dan Provinsi Jambi. Selain dari pusat pembangkit listrik tenaga air, (PLTA) di sekitaran Danau Buatan terdapat obyek wisata berupa panorama alam (hutan dan perbukitan), panorama air (sungai dan danau) serta wisata air terjun yang dialiri dari sungai Kampar kabupaten Kampar Riau. Panorama alam yang begitu indah dikawasan terebut tentunya menjadi potensi yang dapat dikembangkan menjadi Pedapatan Asli Daerah (PAD) dan Desa dari sector kepariwisataan di desa masjid kecamatan XIII koto Kampar Kabupaten Kampar Provinsi Riau.

Indahnya panorama alam di sekitaran PLTA Koto Panjang Kampar menjadikan kawasan tersebut sebagai obyek - obyek wisata yang dapat dikembangkan menjadi kawasan wisata yang dapat dikunjungi oleh masyarakat luas baik dari dalam negeri maupun manca negara. Sala satu upaya yang telah dilakukan oleh sekelompok masyarakat dalam penataan kawasan wisata yaitu membentuk kelompok sadar wisata yang di singkat dengan (POKDARWIS). Organisasi dan Kelembagaan Pokdarwis beranggotakan dari kalangan pemuda yang mempunyai kemauan dan visi bersama untuk mengelola obyek - obyek wisata di kawasan PLTA Dananu buatan koto panjang kabupaten Kampar.

Adapun obyek - obyek wisata yang telah dikembangkan secara konvesional dan dimamfaatkan oleh masyarakat (Pokdarwis Desa Koto Mesjd Kecamatan XIII koto Kampar yaitu : Wisata alam Puncak Kompe, wisata alam puncak khalu khasok, wisata bendungan sungai Kampar,isata alam kebun nangka,Wisata Tambak ikan Danau Buatan PLTA dan Wisata kuliner di sepanjang jembatan danau buatan PLTA koto Panjang. Pengelolaan obyek - obyek wisata yang dilakukan oleh kelompok - kelompok sadar wisata Desa Koto Mesjid dikerjakan secara swadaya masyarakat dengan kemampuan dana dan daya seadanya. Oleh karena itu,harapan masyarakat perlunya perhatian dan dukungan Pemerintahan daerah setempat dan pelaku usaha (Perusahaan) untuk turut serta membangun dan mengembangkan infrastruktur kepariswisataan di kawasan PLTA 
Japs: Jurnal Administrasi Politik dan Sosial, Vol. 1 No 1, April 2020

https://japs.ejournal.unri.ac.id/

koto panjang tersebut karena berdasarkan penelitian yang telah dilakukan oleh (Zakaria \& Suprihardjo, 2014) bahwa pengembangan wisata dilakukan secara spasial dan non spasial yang akan mendukung penngembang objek wisata tersebut.

Pengelolaan kepariwisataan memerlukan keterampilan manajemen yang harus di miliki oleh pengurus maupun anggota organisasi, sehingga tujuan dan hasil yang dinginkan dapat tercapai apabila ada perencanaan dan strategi kebijakan, fasilitas dan aktivitas wisata, pemasaran (Hidayat, 2011). Pada kondisi yang ada pengelolaan pariwisata yang dilakukan oleh kelompok - kelompok sadar wisata Desa Koto Mesjid PLTA koto panjang dimana pengelolaan kepariwisataan masih konvensional, yang hanya mengejar target dan keuntungan dari satu sektor saja, tampa melihat lebih jauh perkembangan wisata yang di inginkan. Sebut saja masyarakat (kelompok) hanya berorientasi pada penerimaan retribusi parkir kendaraan semata - mata, Sementara masih banyak alternative - alternative lain yang perlu dikembangkan terutama berkaitan dengan kerjasama, aksebilitas eksternal, peningkatan kualitas sumber daya manusia, dan pengembangan fasilitas (Masyono \& Suhada, 2015) oleh kelompok (pengurus) dalam mengembangkan aktrasi - aktrasi wisata di sepanjang waduk PLTA koto panjang kabupaten Kampar.

Upaya pengembangan dan pemamfaatan obyek-obyek wisata di kawasan PLTA koto Panjang dengan menghadirkan wisata kuliner, wisata hasil kerajinan masyarakat, wisata seni dan budaya serta wisata sungai (danau) disepanjang Waduk PLTA, Namun, sampai saat ini individu dan kelompok masyarakat belum dapat mengelolah dan mengembangkan obyek-obyek wisata secara baik karena dalam penelitian terdahulu pada pengembangan objek wisata masih mengalami hal yang sama yaitu masalah Dana yang terbatas, lokasi, dan status kepemilikan lahan (Primadany, 2013). Hal tersebut dikarenakan kurangnya pengetahuan dan keterampilan manajemen pengurus, dalam merencanakan, melaksanakan, dan memamfaatkan potensi yang ada dalam pengembangan obyek - obyek wisata di Kawasan danau Buatan PLTA Koto Panjang kabupaten Kampar.

\section{METODE PENELITIAN}

Pendekatan penelitan digunakan adalah action research dengan menelusuri obyek-obyek wisata yang ada di kawasan wisata Danau buatan PLTA Koto Panjang. Untuk memperkuat data dan informasi yang dibutuhkan maka diperoleh jawaban dan keterangan dari beberapa narasumber (informan) yang mengetahui tentang keberadaan 
atau obyek yang di amati. Dengan melakukan survey atau pemetaan, mengambil beberapa gambar (obyek) serta dokumentasi dapat dijadikan alat dan bahan untuk melakukan penganalisaan dari data dan informasi yang telah di peroleh secara baik pada objek penelitian.

\section{HASIL DAN PEMBAHASAN}

Kabupaten Kampar adalah sala satu dari 12 Kabupaten/Kota yang berada dalam wilayah Pemerintahan Provinsi Riau. Kabupaten Kampar memiliki 21 Kecamatan dan 250 Desa/kelurahan. Penelitian yang dilaksanakan dikabupaten Kampar dengan mengangkat kajian tentang Pengembangan kawasan wisata Danau Buatan PLTA Koto Panjang Kampar. Wisata Danau Buatan PLTA Koto panjang terletak di Desa koto masjid kecamatan XIII Koto Kampar Kabupaten Kampar. Desa koto Mesjid memiliki sejumlah obyek Wisata alam (hutan dan danau buatan) berada pada kawasan Pembangkit Listrik tenaga air (PTLA) Danau buatan koto Panjang Kampar,yang dibangun sejak tahun 1993 kerjasama Pemerintah RI dengan Negara Jepang. Wisata alam dan danau buatan PLTA tersebut sangat indah, nyaman dan menarik, sehingga banyak warga atau masyarakat lokal maupun luar daerah berkunjung pada tempat wisata Desa tersebut.

Letak dan posisi Wisata alam desa koto masjid berada pada jalur yang strategis, yaitu terletak dijalan raya lintas ujung barat Riau - sumbar. Bila ditempuh melalui jalan darat memakan waktu selama 2 jam atau jarak tempuh sejauh 98,4 KM Perjalanan dari Ibu Koto Provinsi Riau Kota pekanbaru ke wisata alam danau buatan PLTA Koto Panjang. Selanjutnya bila perjalanan darat dari payakumbuh sumbar- Riau menuju lokasi wisata tersebut dengan menempuh waktu perjalanan selama 30 menit. Letak dan posisi yang strategis di ujung barat kabupaten Kampar Riau dan bertetangga dengan payah kumbuh Sumatera Barat, hingga obyek wisata tersebut mudah dilalui karena kawasan tersebut berada ditepian jalan raya lintas barat Riau-sumbar.

Potensi desa dari sector pariwisata merupakan potensi yang dapat dikembangkan menjadi sumber pendapatan daerah dan Desa. Pendapatan daerah dan Desa dari sector pariwisata tersebut harus dikelola dengn baik yaitu dengan terwujudnya kamauan dan kemandirian desa secara bersama - sama dengan unsur - unsur Desa untuk membangun dan mengembangkan obyek-obyek wisata yang ada dipedesaan. Peningkatan dan pembangunan kepariwisataan diDesa dapat dilakukan dengan pembangunan obyek wisata, baik dalam bentuk mengembangkan obyek wisata yang 
sudah ada maupun membuat obyek-obyek baru sebagai obyek wisata. Adapun obyek obyek wisata alam dan danau buatan PLTA Koto Panjang yang telah dikelola oleh masyarakat Desa koto masjid secara mandiri antara lain :

1. Wisata alam Puncak Kompe.

2. Wisata alam puncak Ulu Kasok.

3. Wisata bendungan PLTA sungai Kampar

4. Wisata pulau tongah di Danau Buatan PLTA Kampar

5. Wisata alam kebun nangka

6. Wisata Tambak ikan Danau Buatan PLTA

7. Wisata kuliner di sepanjang jembatan danau buatan PLTA koto Panjang.

Dari obyek-obyek wisata yang telah ada di Desa mitra maupun yang akan bangun obyek - obyek baru memerlukan peran dan kerjasama dari semua pihak di Desa, sehingga pembangunan obyek pariwisata dapat memberikan dampak sosial dan ekonomi masyarakat Desa. Sala satu upaya yang telah dilakukan oleh sekelompok masyarakat Desa dalam pembangunan dan pengelolaan wisata alam Desa yaitu membentuk kelompok sadar wisata alam (POKDARWIS). Pengurus Pokdarwis terdiri dari kalangan pemuda yang mempunyai kemauan dan visi bersama untuk menata dan memperindah lingkungan alam desa sebagai sebuah obyek atau tujuan wisata.

Pengelolaan obyek - obyek wisata yang dilakukan oleh kelompok - kelompok sadar wisata alam Desa mitra dikerjakan secara swadaya dan gotong royong oleh masyarakat dengan Sumber daya seadanya. Oleh karena itu perlunya perhatian dan dukungan Pemerintahan daerah, Pemerintah Desa serta Pelaku usaha (Perusahaan) untuk berpartisipasi membangun dan mengembangkan obyek-obyek wisata desa yang pada akhirnya dapat meningkatkan perkonomian masyarakat Desa. Pengelolaan kepariwisataan memerlukan keterampilan manajemen yang harus di miliki oleh pengurus maupun anggota organisasi, sehingga tujuan dan hasil yang dinginkan dapat tercapai. Pada kondisi yang ada pengelolaan pariwisata yang dilakukan oleh kelompok kelompok sadar wisata Desa pengelolaanya dilakukan secara konvensional dan hanya mengejar target atau keuntungan satu sector saja, tampa melihat lebih jauh pembangunan jasa dan produk-produk wisata Desa. Sebut saja peran (kelompok) hanya berorientasi pada penerimaan retribusi parkir kendaraan semata - mata,Sementara masih banyak alternative-alternative pengembangan dan pembangunan jasa dan produk wisata desa yang harus di hadirkan untuk memberikan kepuasan pengunjung atas tersedianya produk layanan wisata Desa tersebut. 
Upaya pengembangan dan pemamfaatan obyek-obyek wisata di kawasan PLTA koto Panjang yang memiliki nilai -nilai strategis untuk dikembangkan dengan menghadirkan wisata kuliner, wisata hasil kerajinan masyarakat, wisata seni dan budaya serta wisata sungai (danau) disepanjang Waduk PLTA, Namun, sampai saat ini kelompok sadar wisata Desa belum dapat mengelolah dan mengembangkan obyek obyek wisata secara baik. Hal tersebut dikarenakan kurangnya pengetahuan dan keterampilan manajemen pengurus, dalam merencanakan, melaksanakan, dan memamfaatkan potensi yang ada. Begitu juga dukungan Pemerintah daerah setempat masih rendah dikarenakan keterbatasan dana (anggaran), pembangunan infrastruktur wisata belum memadai, serta Program CSR ( corporate service respontibility) yang belum di mamfaatkan oleh masayarakat secara maksimal.

Pengembangan pariwisata Daerah yang di atur dalam suatu peraturan Daerah diharapkan menjadikan penyelenggaraan pengembangan kepariwisataan di kabupaten Kampar. Pengembangan pariwisata atau siklus hidup pariwisata diharapkan memberikan dampak terhadap daerah atau tujuan wisata yang dimaksud. Pengembangan pariwisata atau sikus hidup pariwisata. Siklus hidup pariwisata (destination area lifecycle) melewati fase-fase di antaranya : (1) Fase exploration (eksplorasi/ penemuan), (2). Fase involment (keterlibatan),(3), Fase development (pembangunan),(4),fase consolidation(konsolidasi),(5) fase stagnation(kestabilan), (6) fase decline (penurunan) dan (7) fase rejuvenation (peremajaan).

Pengembangan obyek pariwisata di Danau buatan PLTA koto panjang dapat disesuaikan dengan siklus atau fase pengembangan sehingga menurut (Osin, Rizky, Kusuma, \& Suryawati, 2019) strategi yang dapat dilakukan dalam upaya mengembangkan produk baru, dalam hal ini bisa memanfaatkan serta mengelola potensi yang dimiliki sehingga bisa menjadi atraksi maupun daya tarik wisata yang baru. Hasil penelitian menggambarkan bahwa kondisi pengembangan obyek wisata danau buatan hanya pada fase eksplorasi dan fase keterlibatan (involment) artinya bahwa kegiatan pengembangan wisata di danau PLTA kito panjang sebatas penemuan obyek wisata baru yang digali atau dikembangkan oleh sebagian kecil kelompok masyarakat atau dengan melibatkan sebagian orang atau kelompok yang berkeinginan mengembangkan obyek-obyek wisata di Danau Buatan PLTA Koto panjang seperti kehadiran kelompok sadarwisata dan ini merupakan bentuk partisipasi nyata masyarakat dalam pengembangan objek wisata (Prabowo, Hamid, \& Prasetya, 2016). Kelompok sadarwisata yang telah dibentuk itupun belum dapat mengembangkan manajemen 
pariwisata dengan tatakelola manajemen yang baik. Kehadiran wisata atau obyek wisata yang dikembangkan oleh sekelompok masyarakat hanya bersifat konvensional yaitu sekedar mengejar keuntungan hasil wisata dari sektor parkir semata-mata tampa memandang aspek - aspek pengembangan produk wisata lainnya sehingga tidak menambahkan faktor-faktor jasa lingkungan non dalamnya dan para stakeholder market sumber daya alam untuk jasa termasuk masyarakat di sekitar lingkungan sosiologi, ekonomi dan kawasan objek wisata) yang pengaruh hubungan tersebut dapat dilihat dari besarnya (Pieter, Benu, \& Kaho, 2015).

\section{KESIMPULAN}

Dalam hal ini terdapat beberapa faktor yang menjadi kendala dalam pengembangan obyek pariwisata di kawasan PLTA Koto panjang Kabupaten Kampar yaitu :

1. Dukungan Pemerintahan Daerah dalam membuat kebijakan pembangunan kawasan wisata belum dapat dilaksanakan karena belum adannya dokumen yang syah dan legal dalam pengembangan kawasan tersebut.

2. Kawasan tersebut adalah milik Perusahaan pembangkit listrik Negara yang memerlukan kesepakatan bersama antara pemerintah Daerah dengan pihak perusahaan PLN koto panjang.

3. Anggaran dan dukungan dana belum tersedia dalam pengembangan, masyarakat hanya menemukan dan mengembangkan kawasan atau viw-viw wisata hanya sumber daya seadanya.

4. Tingkat kunjungan sangaat rendah, karena rata-rata pengunjung hanya datang pada akhir pekan saja, sedangkan pada hari-hari biasa pengunjung sangat sepi.

\section{DAFTAR PUSTAKA:}

Hidayat, M. (2011). Strategi Perencanaan Dan Pengembangan Objek Wisata (Studi Kasus Pantai Pangandaran Kabupaten Ciamis Jawa Barat) Marceilla Hidayat Politeknik Negeri Bandung. Tourism and Hospitality Essentials (THE) Journal, I(1), 33-44. Retrieved from http://ejournal.upi.edu/index.php/thejournal/article/download/1879/1267

Masyono, S., \& Suhada, B. (2015). "Strategi Pengembangan Sektor Kepariwisataan di Kabupaten Lampung Timur.” Journal Derivatif, Volume 9(Nomor 1), 129-139.

Osin, R. F., Rizky, I., Kusuma, W., \& Suryawati, D. A. (2019). Strategi Pengembangan Objek Wisata Kampung Tradisional Bena Kabupaten Ngada-Flores Nusa Tenggara Timur (Ntt). 14(1), 60-65.

Pieter, J., Benu, F., \& Kaho, M. R. (2015). Valuasi Ekonomi Ekowisata terhadap Pengembangan Objek Wisata Kawasan Pesisir. Jurnal Ilmu Lingkungan, 13(1), 55-64. https://doi.org/http://dx.doi.org/10.14710/ji1.13.1.55-64 
Prabowo, S., Hamid, D., \& Prasetya, A. (2016). Analisis Partisipasi Masyarakat Dalam Pengembangan Desa Wisata (Studi Pada Desa Pujonkidul Kecamatan Pujon Kabupaten Malang). Jurnal Administrasi Bisnis S1 Universitas Brawijaya, 33(2), $18-24$.

Primadany, S. (2013). Analisis Strategi Pengembangan Pariwisata Daerah (Studi Pada Dinas Kebudayaan Dan Pariwisata Daerah Kabupaten Nganjuk). Jurnal Administrasi Publik Mahasiswa Universitas Brawijaya, 1(4), 135-143.

Zakaria, F., \& Suprihardjo, D. (2014). Konsep Pengembangan Kawasan Desa Wisata di Desa Bandungan Kecamatan Pakong Kabupaten Pamekasan. Teknik Pomits, 3(2), C245-C249. https://doi.org/2337-3520

UU.No.23 tahun 2014 tentang Pemerintahan daerah UU no.06 tahun 2014 tentang Desa. UU No.10 tahun 2009 tentang kepariwisataan ,jakarta

UU No.50 tahun 2011 tentang Rencana Induk kepariwisataan Nasional.

Rencana induk pengembangan pariwisata Provinsi Riau tahun 2015 